\title{
THE NEBRASKA CONSTITUTIONAL CONVENTION
}

\author{
BY JOHN P. SENNING \\ Unioersity of Nebraska \\ "The mountain was in labor, and Jove was afraid; but it brought \\ forth a mouse." . . . You may think this a too pessimistic view, \\ but the author has given the facts from which to judge. $\quad:$ : :
}

THE adjournment of the Nebraska constitutional convention on March 25,1920 closed a session of seventyfour days. Three hundred and thirtysix proposals were submitted out of which forty-one were selected to be submitted to the people at a special election to be held September 21 . The calling of a constitutional convention to remedy certain defects in the present constitution had long been a subject of earnest discussion. The present constitution was adopted in 1875 during a period of unrest and hard times. It is a document framed for a pioneer state and for many years has seriously hampered the state government by its obsolete provisions and difficulty of amendment. Unfortunately the present constitutional convention was also called at a time when social and economic conditions have produced general distrust and unrest and, as in 1875 , current issues are reflected both in the amendments proposed and those adopted.

\section{THE LEGISLATURE}

A brief survey of the most important points considered by the convention will best illustrate the worth of the work done. As to the legislature and legislative power many changes were proposed but few adopted. There was a strong feeling among the delegates that the patent defects of the bicamera system should be corrected. Proposals were introduced to eliminate the senate and create a single house legislature of about sixty members, but the proposition was defeated on the ground that the people were not ready for such a sweeping innovation. The amendment finally adopted is a step in a backward direction for it provides that the membership in the senate may be increased from its present number, thirty-three, to fifty, just onehalf the size of the lower house. The salary of senators and representatives is to be $\$ 800$ for a regular session, instead of $\$ 600$ as at present, and $\$ 10$ a day for a special session, though the total amount for a special session cannot exceed $\$ 100$.

In procedure three items should be noted. The old provision that the minimum length of a regular session must be sixty days has been eliminated, making it possible for a legislature to meet for a shorter period if the volume of business is not great enough to warrant spending more than two months upon it. It has long been apparent that conference reports and amendments to important bills have been passed during the closing days of the session when there was not a full attendance. The convention proposes to remedy that evil by providing that conference committee reports and 
amendments shall be concurred in by the same vote as that required for the passage of the original bill. Within the past two years, besides a regular session of approximately ninety days, two special sessions had to be called, one to ratify the federal suffrage amendment and the other to enable Douglas County to issue bonds to rebuild its court house which had been seriously damaged by a mob. Except for the provision that bills must be read on three separate days the business of each special session could have easily been transacted in one day. The experience of these two sessions together with the common practice of ignoring the provision during regular sessions emphasized the need of changing that portion of the constitution which requires that bills must be read on three different days. This section has therefore been eliminated, leaving the time intervening between the first and final reading of a bill to be determined by the rules.

\section{THE INITLATIVE AND REFERENDUM}

As in every constitutional convention of recent date the initiative and referendum came in for a share of attention. Nebraska adopted the initiative and referendum amendments in 1912 , but the experience of eight years has revealed certain defects in these provisions. One example may suffice for explanation. During the summer of 1919 petitions were circulated to secure a referendum upon the civil administrative code. It was impracticable to attach a copy of the law, which contained several hundred pages, to each petition. The circulators satisfied themselves by attaching a few general statements concerning the bill to the petition and in that manner secured a sufficient number of signatures. Such a practice seemed to be in open conflict with express statutory provisions that the entire law should be attached to the petition. The court, however, held, in the mandamus proceedings to compel the secretary of state to receive the petitions, that the spirit of the constitution should control. The matter of fictitious signatures was also discussed. It was suggested that a referendum petition should be signed in the presence of an officer; that instead of soliciting signatures among the electorate, those interested in the referendum should go to a central office and sign the petition in the presence of a designated official. The net result of many hours spent on the initiative and referendum was (1) the reduction of the number of signatures from 10 per cent to 7 per cent and (2) that the title of the law only need be attached to the petition.

\section{ADMINISTRATIVE REORGANIZATION}

In executive organization the short ballot idea was regarded with scant favor by the convention. Three distinct proposals modifying the present executive and administrative system were introduced. One called for the election of the governor and a board of six directors and for the creation of seven departments. The directors were to be elected by districts and they, with the governor, were to make all appointments. A second provided for the creation of ten departments. The governor, lieutenant governor, auditor, and treasurer were to be elected by the people and were to appoint the heads of the various departments. A third left on the ballot only the governor, the lieutenant governor and auditor. Near the close of the convention a fourth proposal was brought in by the committee on executive reorganization which disregarded the provisions of the first two and provided for the election 
of four executive officers, giving the governor power to appoint all others. By this time such a state of feeling had developed among the various leaders that not even a compromise proposal was possible. The amendment to be submitted to the people, therefore, retains all the present state officers, who shall serve for a term of two years, except the superintendent of public instruction whose term of office shall be four years. An important appointive officer, the tax commissioner, is added to the present list. $\mathrm{He}$ is to be appointed by the governor with the advice and consent of the senate.

Two provisions of the present constitution which perhaps were used with better effect than any others to convince the people of the wisdom of calling a constitutional convention are the one which prevents the creation of additional executive offices and the other which makes "no allowance for clerk hire in the offices of the superintendent of public instruction and attorney general." To keep within the limits of the constitution, deputies, boards and commissions have been created with one of the executive officers, usually the governor, at the head. By a ruling of the supreme court it was decided that "clerk" did not mean "stenographer," but subterfuges have been most unsatisfactory. The proposed amendments eliminate the clause concerning "clerk hire" and allow the creation of new executive offices by a vote of two-thirds majority of all members elected to the senate and house. The heads of the new departments are to be appointed by the governor and the appointments ratified by a majority of the members elected to the upper and lower house in joint session. It is to be noted that the convention made the appointive power of the governor subject to modified restrictions. The tax commis- sioner is appointed by the governor with the advice and consent of the senate; the heads of the new departments as given above. The office force within these departments are appointed by the department heads. The appointments to the board of control require the consent of twothirds of the members elected to the senate; and judicial officers appointed to fill vacancies require no confirmation at all.

Popular distrust of a strong executive is reflected in the budget proposal, which adds very little to the statutory budget which became a law in 1915 . The governor is required to prepare a budget and to have expert assistance in so doing, subject to the regulations provided by law. His estimates as submitted in the itemized budget cannot be increased except by a threefifths vote of the legislature. No provision is made for supplementary appropriations. In one respect the governor's power has actually been reduced, namely, his pardoning power. Instead of leaving pardons to the governor alone a board has been created consisting of the governor, the secretary of state and attorney general, which has complete control over all pardons, paroles and commutations.

Regulation of salary, which heretofore was fixed in the constitution, is to be left to the legislature, though changes cannot be made more often than once in eight years. For the present the convention has adopted a scale giving the governor $\$ 7,500$, the other state officers except the lieutenant governor, $\$ 5,000$, and the lieutenant governor twice the compensation of a state senator. Members of the railway commission whose duties have been enlarged to take in all public service corporations are to receive $\$ 7,500$ each, an increase of $\$ 4,500$ over their present salary. 
THE JUDICIARY DEPARTMENT

The chief changes proposed in the judiciary of the state are with a view of expediting business. It is impossible for the supreme court to keep its docket up to date. Some years ago a supreme court commission was created but in spite of this extra assistance, the court has been unable to keep up with the volume of business which comes from the lower courts. It is proposed that the supreme court sit in sections and call to its assistance judges of the district court. A most notable change suggested is that which grants judges of the supreme court power to make rules of procedure for the respective grades of courts. This provision, if carried out, will no doubt go far toward eliminating the technicalities and rules established by law and thus shorten the route any case may take from its original hearing to final decision. Cases brought before the court involving the constitutionality of the law will require the concurrence of five out of the seven judges of the supreme court. The term of office remains unchanged. The methods of election are modified also. Instead of electing supreme judges at large, as heretofore, the new proposal makes all except the chief justice elected by individual districts. The idea of election by districts had a strong hold upon the convention, and it is provided that the six regents of the state university be elected by districts. Attempts were made to have the three members of the railway commission also elected by districts; fortunately this proposal failed of adoption.

\section{TAXATION AND FINANCE}

The amendments to the article on taxation and revenue do not reflect the highest credit upon the convention. In the campaign before the convention no subject was as much discussed as the tax amendments to the constitution. In the convention two extreme views were represented. One sought to leave the entire question of taxation to the legislature as does Connecticut; and the other contended for a detailed classification. The result was a compromise between the two views. The present constitution contains only a general property tax provision. Valuation must be uniform as to class. The new proposal retains this portion but adds "that taxes other than property taxes may be authorized by law." Household goods to the value of $\$ 200$ are exempted from taxation. The legislature has no discretion whatever in making any exemptions. County authorities are limited to an aggregate assessment of fifty cents per one hundred dollars actual valuation, unless authorized by vote of the people in order to meet an emergency. The convention missed a great opportunity in not standing for a real progressive tax provision.

\section{CORPORATIONS}

The amount of attention paid to corporations in the convention clearly shows that Nebraska has entered upon a new stage of development. It is no longer a purely agricultural state. Both private and public corporations are great economic factors of which the constitutional convention had to take cognizance. As to private corporations the provision in the present constitution is purely negative. The new proposal is mandatory upon the legislature to enact adequate laws for the development of corporations, domestic and foreign, under proper restrictions designed to prevent reckless speculation, monopoly and discrimination. Ample provision is made for the development of co-operative companies and 
associations along the line of co-operative principles. Public utility corporations will be required to render account to the railway commission as the law may direct or may be ordered by the commission. They may consolidate their stock when authorized by the railway commission and by law may be required to facilitate an exchange of business. The present constitution prohibits consolidation altogether. Dividends can be declared only out of net earnings which are also defined. The new proposal applies to all public utilities and is much more explicit than the present provision which related only to railroads.

\section{LOCAL GOVERNMENT}

Counties and cities, as local governments, received scant attention at the hands of the convention. County government as such was left untouched. The existing statute regarding change of boundary is the only proposal on counties to be submitted to the voters. The proposal relating to cities merely facilitates the method by which cities of 100,000 inhabitants and over may obtain: home rule charters. Omaha is the only city to which this can apply. Heretofore if a city of that class adopted the principle of home rule it was necessary to call into existence the machinery of a convention to adopt a new charter. The new amendment makes such a process unnecessary. If a city decides in favor of home rule the existing charter is declared to be a home rule charter.

\section{INDUSTRIAL RELATIONS}

There is probably no action taken by the convention which will cause more discussion or meet with greater opposition than the proposal to create an industrial commission to regulate and settle differences between employers and employes. The language of this section is all inclusive. "Laws may be enacted providing for the investigation, submission and determination of controversies between employers and employes in any business or vocation affected with a public interest and for the prevention of unfair business practices and unconscionable gains in any business or vocation affecting the public welfare. An industrial commission may be created for the purpose of administering such laws, and appeals shall lie to the supreme court from the final orders and judgments of such commission."

\section{SUFFRAGE AND EDCCATION}

The equal suffrage amendment was passed with no opposition. Thus the struggle begun by the submission of an amendment in 1882 was finally ended. Provision has also been made for the exercise of the right of suffrage on the part of men in the service of the army or navy.

Proposals adopted by the convention in regard to education effected only minor changes. Educational leaders in the state presented an elaborate plan early in the session for an educational reorganization modelled on the New York system. Another proposal was introduced making permanent appropriations for educational institutions. Out of a wealth of discussion the following meagre results emergedthe normal schools were placed under a single board appointed by the governor, a provision which is already on the statute books; the term of office of the superintendent of public instruction was increased from two to four years; school lands, if the legislature shall decree that any shall pass out of the hands of the state, shall be sold only at public auction. 


\section{AN IMPROVED AMENDING PROCESS}

One of the most commendatory amendments worked out by the convention is that which facilitates the process of amending the constitution. According to the existing provision a majority of all the votes cast at the election is necessary to ratify an amendment submitted to the voters. The new proposal places the amendment upon a separate ballot, and if it receives a majority of those voting on the proposition, provided that is $\mathbf{3 5}$ per cent of the vote cast, it is declared adopted. This section opens the way to future changes in the constitution and will enable the people to enact those provisions which the convention overlooked.

WAS THE CONVENTION WORTH WHILE?

On the whole the action of the $\mathrm{Ne}$ braska convention was very conservative. The changes in the structure of both legislative and administrative systems ignore entirely modern scientific principles of government. Whether the amendments adopted by the convention in respect to the judiciary are an improvement upon the old is merely a matter of individual opinion. The delegates were more interested in correcting certain existing abuses than in building a constitution for the future. Recent writers have observed that constitutional conventions are influenced primarily by current events. As a result matter is incorporated into the constitution which is private and not public law. The Nebraska convention was no exception to this rule. For example the section making English the official language was merely the outcome of a long struggle to compel the use of English in the schools. Again the amendment that the legislature shall regulate the acquisition, enjoyment and descent of property of aliens is an aftermath of the reaction against aliens during the late war. The present unrest over labor conditions resulted in a minimum wage amendment being submitted and also in the creation of an industrial commission. The reorganization of the administrative system in 1919 encountered serious opposition and probably was responsible for the defeat of the short ballot propositions in the convention. The creation of a board of pardons was due to the widespread discussion of the parole of a prisoner by the president of the senate acting as governor during the absence from the state of both governor and lieutenant governor. The unwillingness of the convention to build well by modelling a constitution which would be adequate for the future development of the state and by bringing into existence a responsible government cannot be attributed to any partisan feeling. Time and circumstances only are responsible for any inadequacies in the proposed revision of the Nebraska constitution. If the proposal facilitating amendment is adopted by the people there is no doubt that the shortcoming of the present constitutional convention will soon be corrected. 